\title{
Strani maloljetnici bez pratnje u Republici Hrvatskoj: problematika učenja jezika i obrazovanja
}

DOI: $10.11567 /$ met.31.3.1 UDK: 314.745.3-054.7-053.4/.6(497.5):[81'243+37

Izvorni znanstveni rad

Primljeno: 02. 12. 2015.

Prihvaćeno: 17. 03. 2016.

\author{
Drago Župarić-Iljić
}

Institut za migracije i narodnosti

drago.zuparic@imin.hr

\section{Dubravka Mlinarić}

Institut za migracije i narodnosti

dubravka.mlinaric@imin.hr

\section{SAŽETAK}

Suvremeni mješoviti migracijski tokovi uključuju i djecu odvojenu od roditelja te maloljetnike bez pratnje, koji se svrstavaju među najranjivije skupine migranata. Od 2006. do srpnja 2014. u Hrvatskoj je registrirano ukupno 3255 stranih maloljetnika bez pratnje, od čega oko četiristo maloljetnih tražitelja azila, najviše državljana Afganistana, Pakistana i Somalije. Uočljiv je fenomen da se u institucijama kojima su povjereni na skrb oni zadržavaju kratko te ih samovoljno napuštaju unutar svega nekoliko tjedana od dana dolaska. Politike i mjere usmjerene skrbi i zaštiti stranih maloljetnika bez pratnje uključuju državne mehanizme u domeni utvrđivanja identiteta i dobi maloljetnika, dodjeljivanja skrbnika, osiguravanja smještaja i slobode kretanja, pravne i financijske podrške, zdravstvene i socijalne skrbi, učenja jezika, obrazovanja te osiguravanja njihove reunifikacije s obitelji. U ovom se radu fokusira na analizu politika i mjera vezanih uz učenje jezika i obrazovanje stranih maloljetnika bez pratnje, što je jedan od temeljnih preduvjeta njihova uključivanja u društvo. $\mathrm{Na}$ temelju provedenog istraživanja metodom intervjua među relevantnim akterima uključenim u sustav njihove zaštite i skrbi analiziraju se neki od najvažnijih izazova, prije svega u području obrazovne, ali i šire integracije stranih maloljetnika bez pratnje. Preliminarni rezultati navode na zaključak kako njihov kratkotrajni boravak u Hrvatskoj i rano napuštanje sustava onemogućuju realizaciju državnog programa skrbi zajamčenog zakonskim okvirom, što državu dijelom priječi u sustavnom i učinkovitom planiranju i realizaciji daljnjih aktivnosti u obrazovanju djece stranaca. Manjak međuresorne i unutarresorne koordiniranosti državnog sektora rezultira u ovom području institucionalnim poteškoćama i nedosljednošću u implementaciji postojeće nacionalne regulative i europskih standarda.

KLJUČNE RIJEČI: strani maloljetnici bez pratnje, učenje jezika, obrazovanje, integracijske politike, Hrvatska 


\section{UVOD}

U suvremenom svijetu fenomen migracija, pa tako i migracija djece, tj. maloljetnika bez pratnje, posebno je složen i višeznačan. Mnogim je maloljetnim migrantima, jednako kao i odraslima, čin migracije ne samo eventualna prilika za bolji život nego nerijetko i preduvjet golog preživljavanja u bijegu iz konfliktnih zona, gdje su im život i sloboda ugroženi. Pitanje osobne sigurnosti za djecu migrante i za članove njihovih obitelji dodatno se aktualiziralo velikim izbjegličkim i migrantskim tokovima u 2015. Hrvatska je i prije punopravnog članstva u EU-u bila važan tranzitni teritorij na tzv. balkanskoj migracijskoj ruti, interesantna upravo zbog svoga specifičnoga geostrateškog položaja, koji povezuje jugoistok Europe s njegovim središnjim i zapadnim dijelovima. Stoga ostaje jedna od usputnih postaja na putu prolaska brojnih tražitelja zaštite i drugih migranata koji, uglavnom neregularno, putuju do željenih destinacija Zapadne Europe. Neki od njih na tom putu ipak bivaju zaustavljeni u Hrvatskoj. Potom traže zaštitu pa neko vrijeme do donošenja odluke o njihovu statusu i priznanja prava na zaštitu borave u Hrvatskoj (Valenta, Zuparic-Iljic i Vidovic, 2015). Ostali nakon mjere pritvora te izricanja mjere za napuštanje hrvatskog teritorija uglavnom to i učine, najčešće $u$ daljnjemu neregularnom tranzitiranju prema zemljama Zapadne Europe.

Od ljeta 2015. svjedočimo humanitarnoj krizi koja je vezana uz dolazak velikog broja izbjeglica iz Sirije, Iraka i Afganistana te drugih prisilnih migranata koji u mješovitome migrantskom toku dolaze preko istočnoeuropske i balkanske rute u zapadnoeuropske zemlje. Ne postoje točni podaci o broju stranih maloljetnika bez pratnje koji su se u aktualnom toku zatekli u Hrvatskoj, no postoje procjene kako samo od rujna do prosinca 2015. ukupno 225.000 djece, kao posebno ranjive skupine, treba neku vrstu asistencije na svom putu u nekoj od zemalja Balkanske rute (koja počinje u Grčkoj, a završava u Njemačkoj) (UNICEF, 2015). Iako je razdvajanje obitelji nerijetka pojava u masovnim izbjegličkim tokovima, neke naznake govore kako je u situaciji tranzitnog prihvata u Hrvatskoj bilo tek nekoliko slučajeva djece bez pratnje $\mathrm{u}$ prihvatnome tranzitnom kampu u Opatovcu ${ }^{1}$ te kako se broj slučajeva odvajanja od obitelji znatno smanjio organizacijom izravnog transfera od mjesta ulaska u Hrvatsku (prijelaz Šid-Tovarnik) do kampa u Slavonskom Brodu.

No bez obzira na trenutačnu situaciju, tijekom posljednjih dvadesetak godina u Hrvatskoj raste broj zatečene djece, tj. stranih maloljetnika bez

Vidi: http://izbjeglice.hrt.hr/306650/children-without-parents-along-the-balkan-migrationroute-does-anyone-speak-urdu (30. 01. 2016.). 
pratnje $\mathrm{u}$ nezakonitom prelasku državne granice, odnosno $\mathrm{u}$ ukupnom udjelu »neregularnih migranata «, tražitelja azila ili žrtava trgovine ljudima. Zbog toga je dugi niz godina ta tema vrlo aktualna iako je relativno slabo istražena u hrvatskom kontekstu. Nameće se pitanje do koje mjere proklamirane i propisane državne politike prema stranim maloljetnicima bez pratnje korespondiraju s praksama njihove implementacije na različitim područjima. Nadalje, ima li napretka u organizaciji skrbi za maloljetnike od identifikacije problema ranih devedesetih preko pretpristupnog razdoblja ulaska Hrvatske u EU do danas, s obzirom na implementaciju novih regulativa Europske unije, ali i vlastito iskustvo?

Iako u radu sa stranim maloljetnicima bez pratnje postoje brojne dimenzije, u ovom radu istražujemo opća pitanja njihova statusa u Hrvatskoj, a posebno ostvarenje njihova prava na učenje jezika i obrazovanje. Iz makroperspektive bavimo se prije svega analizom pravnih i institucionalnih aspekata učenja jezika i obrazovanja stranih maloljetnika bez pratnje u Hrvatskoj u fazi postmigracije te njihove daljnje tranzitne migracije. Fokus je dakle na državnim politikama i praksama vezanim uz jezične i obrazovne aspekte integracije te ranjive skupine migranata. Uz državne službenike integracijske mjere provode i drugi akteri uključeni u rad sa stranim maloljetnicima bez pratnje, u procesu koji traje od njihova registriranja u Hrvatskoj, tijekom cijelog boravka pa sve do odlaska iz sustava.

Ovim ćemo radom pokušati odgovoriti na pitanja tko su strani maloljetnici bez pratnje, koliko ih je boravilo u Hrvatskoj i u tranzitu prošlo kroz nju, koje su opće karakteristike njihova pravnog statusa i položaja u društvu te posebno razmotriti odgovor hrvatskoga obrazovnog sustava i drugih aktera na njihovu specifičnu situaciju, potrebe i perspektive. U iduća dva poglavlja iznose se teorijski i metodološki pristup istraživanju navedenog problema te ograničenja s kojima se pritom susrelo.

\section{CILJ, PRISTUP, METODOLOGIJA I OGRANIČENJA ISTRAŽIVANJA}

Ovaj je rad dio istraživanja čiji je opći cilj bio opisati pravne, institucionalne i praktične aspekte politika i mjera integracije stranih maloljetnika u hrvatsko društvo u aspektima prihvata, smještaja, procjene dobi, dodjeljivanja skrbnika, pružanja medicinske i socijalne skrbi, uključivanja u obrazovni proces te ostvarenja svih ostalih prava koja se tiču posebnih potreba djece kao posebno ranjive kategorije migranata i izbjeglica. No posebni cilj ovog rada jest analiza politika i mjera vezanih uz učenje hrvatskog jezika 
i uz pristup obrazovanju za populaciju stranih maloljetnika bez pratnje $u$ Hrvatskoj.

U istraživanju provedenome među akterima uključenim u sustav zaštite i skrbi maloljetnika analizirali smo neke od najvažnijih izazova u području položaja i prava te šire integracije stranih maloljetnika bez pratnje u društvo. Istraživanje je provedeno od svibnja do srpnja 2014. i temeljilo se na kvalitativnoj metodologiji, sukladno smjernicama u Bryman (2008: 195214). Uključivalo je pregled postojećih istraživanja na tu temu, desk study analizu dostupne dokumentacije (posebice zakona i pravilnika koji uređuju područje obrazovanja i migracija) te tematsku analizu sadržaja transkripata trinaest provedenih ekspertnih, polustrukturiranih intervjua (UMQ1$\mathrm{UMQ13})^{2}$ i informacija dobivenih putem korespondencije elektroničkom poštom s najrelevantnijim nacionalnim institucijama, lokalnim akterima i organizacijama civilnog društva koje se bave ostvarivanjem i zaštitom prava tražitelja zaštite te stranih maloljetnika bez pratnje.

Metodološko utemeljenje ovog istraživanja počiva na kombinaciji pristupa koja uključuje pregled dosadašnjih istraživanja, analizu pisanih izvo$\mathrm{ra}, \mathrm{tj}$. dokumenata $\mathrm{u}$ obliku pravne regulative te empirijske podatke i uvide $\mathrm{s}$ terena prikupljene metodom intervjua. ${ }^{3}$ Budući da se triangulacija odnosi uglavnom na upotrebu »višestrukih promatrača, teorijskih perspektiva, izvora podataka i metodologija « (Denzin, 1970: 310, prema Bryman, 2008: 379), u istraživanju smo se služili višestrukim izvorima podataka i metodama analize kako bi rezultati bili što vjerodostojniji. U tom je smislu metoda induktivna i interpretativna s fokusom na analizu javnih politika i stvarnih praksi u interaktivnome istraživačkom procesu koji je uključivao komunikaciju istraživačâ i društvenih aktera, tj. provoditeljâ politika spram stranih maloljetnika bez pratnje. ${ }^{4}$

Na temelju provedenih intervjua dobili smo uvid u aktivnosti Vladinih tijela, koje ćemo u daljnjem tekstu navoditi ovdje naznačenim kraticama:

Kratica UMQ (Unaccompanied Minors Questionnaire) označuje provedeni upitnik, tj. transkript pod određenim rednim brojem koji je ujedno kodna oznaka sudionika/ice iz istraživanja. Svi su intervju provedeni na engleskom jeziku, a za potrebe ovog rada autori su ih preveli na hrvatski.

3 U radu, uz temeljitu analizu sekundarne literature, predstavljamo preliminarne rezultate terenskog istraživanja koje je provedeno kao dio istraživanja studentice Ting Ting Unaccompanied Minors in Croatia - A Comparative Perspective, Analysing the Polices vs. Practices tijekom njezina boravka na studentskoj razmjeni u Hrvatskoj (Ting, 2014). Ono je provedeno u okviru suradnje Instituta za migracije i narodnosti iz Zagreba i Sveučilišta u Stavangeru (Norveška) kao dio stručne prakse stranih studenata na studiju European Master in Migration and Intercultural Relations (EMMIR). Stručna praksa u okviru razmjene studenata realizirana je u suradnji s dr. sc. Ružicom Čičak-Chand.

4 Za karakteristike kvalitativnih istraživanja, njihove epistemološke temelje te posebnosti istraživačkih metoda i ciljeva vidi više u Flick (1998) i Bryman (2008). 
Ministarstva unutarnjih poslova (MUP), Ministarstva socijalne politike i mladih (MSPM), centara za socijalnu skrb (CZSS), Doma za odgoj djece i mladih Dugave (DODM), osnovnoškolskih i srednjoškolskih ustanova u Kutini i Zagrebu (OŠ i SŠ), međunarodnih agencija (UNHCR) te domaćih organizacija civilnog društva (OCD - Hrvatskoga pravnog centra, Centra za mirovne studije i Centra za nove inicijative), Hrvatskoga Crvenoga križa (HCK) i posebnih lokalnih aktera poput kulturne institucije Gradske knjižnice Kutina ili vjerske ustanove poput Evangeličke luteranske crkve u Kutini, koje su sve provodile određene mjere i aktivnosti usmjerene na strane maloljetnike bez pratnje i širu populaciju osoba pod zaštitom.

Učenje jezika i obrazovanje jedan su od temeljnih preduvjeta primarnog uključivanja stranih maloljetnika u društvo. No u istraživanje nije uključena mikrodimenzija analize, tj. način na koji sama interakcija stranih maloljetnika bez pratnje s hrvatskim školskim sustavom oblikuje njihovu svakodnevicu u Hrvatskoj, utječe na stupnjeve jezične integracije i socijalizacije te na sam školski uspjeh s obzirom na njihovo predznanje, obrazovne temelje i osobne karakteristike.

Zbog složenosti istraživanog problema, etičke osjetljivosti teme te ograničenosti pristupa djeci strancima kao potencijalnim sugovornicima kontakt bilo kojeg oblika sa stranim maloljetnicima u istraživanju nije ostvaren, čime ova studija zasigurno ostaje zakinuta za dimenziju viđenja problema iz gledišta samih korisnika programa. ${ }^{5}$ No usporedbe s državama koje su provele takva istraživanja s ciljem proučavanja školskog uspjeha djece i zapreka $\mathrm{u}$ tom procesu provedene su uglavnom u društvima koja imaju znatniju tradiciju imigracije, tj. značajniji postotak useljenika svih statusa u općoj i ukupnoj školskoj populaciji. Ondje se, za razliku od Hrvatske, ta djeca zadržavaju i u tim društvima odrastaju, što onda omogućuje dublju i longitudinalnu analizu kvalitete njihove socijalne interakcije u školskom okružju (Due i Riggs, 2009). Stoga se postavlja pitanje: tko su uopće strani maloljetnici ili djeca bez pratnje i što dosadašnja istraživanja govore o tom fenomenu unutar školskog sustava kao i okružju šire zajednice $u$ društvu primitka u kojem se nalaze?

Kod istraživanja ove tematike naročito je važno teorijsko-metodološko polazište »postmigracijske ekologije«. Ono možda ponajbolje objašnjava recipročnost odnosa djeteta bez pratnje (sa svim njegovim individualnim iskustvima) i škole kao nove referentne okoline u kojoj se ono nastoji snaći i uspjeti. Koncept je preuzet iz psihologijske teorije o »ekologiji ljudskog razvoja « Urieja Bronfenbrennera, a podrobnije razrađen i primijenjen u Anderson i sur. (2004) te Nilsson i Bunar (2015). To polazište omogućuje »analizu niza isprepletenih politika, strategija, kategorizacija i narativa koji obuhvaćaju pravne, organizacijske i pedagoške odgovore spram novopridošlih učenika« (Nilsson i Bunar, 2015: 13). 


\section{DEFINICIJE OSNOVNIH POJMOVA I TEORIJSKA UTEMELJENOST ISTRAŽIVANJA}

Osnovni pojmovi koje upotrebljavamo u ovom radu ponajprije su sociopravnička određenja fenomena koji smo istraživali. Tijekom prethodna dva desetljeća pojmovna definicija »djece bez pratnje « naslanjala se na međunarodne pravne uzuse zaštite poput Konvencije o pravima djeteta $\mathrm{UN}-\mathrm{a},{ }^{6}$ nediskriminaciju i zaštitu najboljih interesa djeteta, a unutar njih i pravo na obrazovanje i slobodno vrijeme (čl. 28 - 31), kao i čl. 3 Ustava RH i stavak o respektiranju ljudskih prava (Kraljević, Marinović i Žigante Živković, 2011: 15, 30, 35). No u hrvatskom kontekstu tek je Protokol o postupanju prema djeci odvojenoj od roditelja - stranim državljanima (dalje: Protokol), donesen 18. srpnja 2013., definirao da je »dijete odvojeno od roditelja-strani državljanin (...) osoba mlađa od 18 godina koja nije državljanin $\mathrm{RH},[\mathrm{a}]$ nalazi se izvan svoje zemlje podrijetla ili prebivališta bez pratnje zakonskog zastupnika (roditelj ili skrbnik) ili druge osobe kojoj je zakonski zastupnik povjerio dijete na pravno valjani način, a u RH boravi nezakonito ili kao tražitelj azila« (Vlada RH, 2013a). ${ }^{7}$

U ovom radu odlučili smo se za učestaliju upotrebu izraza »strani maloljetnici bez pratnje«, čime obuhvaćamo uvriježene i jednako validne sintagme iz Konvencije o pravima djeteta, koja spominje »djecu bez pratnje« (unaccompanied children), odnosno »djecu odvojenu od roditelja (separated children). UNHCR (2008: 8) naglašava da je krucijalna razlika u tome što je dijete ili maloljetnik bez pratnje odvojen od oba roditelja i drugih rođaka, a istovremeno se za njega ne skrbi punoljetna osoba koja bi za to trebala biti odgovorna prema zakonu ili običajima, dok djeca odvojena od roditelja mogu biti u pratnji drugih članova rodbine, pogotovo one daljnje, ali ne i svojih roditelja i drugih bližih skrbnika. Strani maloljetnici bez pratnje koji neregularno ulaze u RH u statusu su stranih maloljetnika - nezakonitih migranata, a ako zatraže zaštitu, tada su strani maloljetnici - tražitelji zaštite.

Europska i svjetska iskustva istraživanja fenomena djece izbjeglica i maloljetnika bez pratnje raznolika su, polazeći od različitih teorijskih perspektiva i fokusa u istraživanjima (Anderson, 2001; Bhabha, 2004; Watters,

6 Članak 27. Konvencije o pravima djeteta UN-a nalaže strankama da »omoguće pravo svakom djetetu na životni standard adekvatan njegovom fizičkom, mentalnom, duhovnom, moralnom i društvenom razvoju« (UN, 1989: 8).

7 Sukladno Zakonu o međunarodnoj i privremenoj zaštiti (NN 70/15, čl. 4, st. 17): »Dijete bez pratnje je državljanin treće zemlje ili osoba bez državljanstva mlađa od osamnaest godina, koja je ušla u Republiku Hrvatsku bez pratnje odrasle osobe odgovorne za njega u smislu roditeljske skrbi sukladno zakonodavstvu Republike Hrvatske, sve dok se ne stavi pod skrb takve osobe, a uključuje i djecu koja su ostala bez pratnje nakon što su ušla u Republiku Hrvatsku.« 
2008; Marsh, 2012). No tek se relativno odnedavno ta tema nametnula kao važno istraživačko pitanje u polju migracijskih i izbjegličkih studija, iako se relativno duže obrađuje u psihologiji i pedagogiji. Bhabha (2004) ustvrđuje kako su istraživanja koja se tiču izbjeglica dugo minimizirala problem djece izbjeglica, naročito onih bez pratnje, jer je fokus oduvijek bio većinom na odraslima i njihovu iskustvu raseljenosti. Time su djeca tražitelji zaštite $\mathrm{u}$ istraživanjima bila nevidljiva i marginalizirana, iako je njihov položaj u društvima primitka bio zabrinjavajući, s nastavkom traumatičnih iskustava koja mogu proizlaziti kako iz područja porijekla tako i iz mjera isključivanja i ignoriranja u društvima primitka.

Prema istraživanjima Watters (2008) i Ensor (2010), strani maloljetnici bez pratnje sastavni su dio mješovitih migracijskih tokova potaknutih političkim nestabilnostima, ekonomskom ugroženošću i negativnim posljedicama promjena u ljudskom i prirodnom okolišu. Iako na put mogu krenuti s članovima svoje uže ili šire obitelji, odvajanje maloljetnika od njihovih obitelji moguće je u bilo kojoj fazi putovanja. Svi ti procesi mogu voditi do fizičke, psihološke i emocionalne ugroženosti i traume maloljetnika čineći ih jednom od posebno ranjivih skupina migranata, vrlo osjetljivom na nasilje i izrabljivanje. Istraživanja ističu nesigurnost pravnog statusa djece migranata kao jednu od važnijih predominanti njihova emocionalnog i psihosocijalnog stanja, što se onda odražava na njihov školski (ne)uspjeh (Anderson, 2001).

Komplementarno s istraživanjima ovog fenomena iz pravne perspektive, ona iz psihologijske perspektive usmjerena su na propitivanja sustava prihvata i skrbi te psihofizičke, emocionalne i svake druge dobrobiti djeteta (neovisno o pravom statusu koje ima u društvu primitka). Na primjeru belgijskog sustava prihvata djece migranata Derluyn i Broekaert (2008) pokazuju da ako taj fenomen promatramo samo iz pravne perspektive, onda su minimalni standardi u sustavu prihvata i skrbi lošiji za djecu migrante nego za domicilne maloljetnike te zanemaruju njihovu specifičnu situaciju i potrebe. I australsko društvo, koje je mnogo dalje odmaklo u osmišljavanju integracijskih politika, svakodnevno se susreće s "prenormiranjem « integracijskih politika sukladno interesima nacionalne države i nametanju određenog »načina života« koji pretvara djecu-strance u autsajdere, jača socijalnu isključivost i ignorira njihove specifične potrebe (Due i Riggs, 2009: 63). Sve to može voditi retraumatizaciji djeteta te bitno smanjiti njegov obrazovni uspjeh i svaku daljnju integraciju u društvo.

Sukladno tome postoje istraživanja o tome na koje sve načine faze migracijskog iskustva (predmigracijska, transmigracijska i postmigracijska) 
utječu na obrazovne mogućnosti i uspjehe djece migranata i izbjeglica u sustavu obrazovanja. Prema Anderson i sur. (2004: 5), ta se istraživanja bave temama poput: školskog uspjeha i mentalnog zdravlja djece izbjeglica s obzirom na proživljenu traumu, obrazovnih šansi s obzirom na iskustvo raseljenosti i akulturacije, potreba jezičnih i kulturnih manjina, opće otpornosti djeteta te inkluzivnog obrazovanja i specijalnih potreba te populacije. Najčešći problemi s kojima se susreću djeca izbjeglice (a što može važiti u velikoj mjeri i za djecu tražitelje azila kao i za strane maloljetnike bez pratnje) proizlaze iz neriješenosti njihova pravnog statusa, nedostatnoga društvenoga kapitala i nepostojanja društvenih mreža, njihove česte socioekonomske depriviranosti i strukturne marginaliziranosti. Istraživači upozoravaju kako sve to može voditi konfliktima i nasilju od djece izbjeglica i prema djeci izbjeglicama unutar školskoga sustava (npr. bullyingu). Pritom nerijetko izostaju pomoć i podrška obrazovnog sustava, tj. njegovih djelatnika za djecu izbjeglice, a njihova viktimizacija i retraumatizacija često se mogu nastaviti (Watters, 2008; Pinson, Arnot i Candappa, 2010).

Nerijetko se negativne životne okolnosti s kojima se djeca izbjeglice i tražitelji azila suočavaju promatraju samo kroz prizmu deficita s obzirom na njihova traumatična iskustva, nesiguran pravni status i jezične barijere. No prenaglašavanjem toga zapravo se zanemaruje stvarni obrazovni kapacitet tih učenika, a sustav kroz takvu prizmu ustvari reproducira problem koji nastoji riješiti (Nilsson i Bunar, 2015: 2). Stoga u posljednje vrijeme postoje i istraživanja koja ne gledaju na »djecu migrante« kao na isključivo pasivne i ranjive žrtve, već kao na aktivne osobe čiji migracijski čin može također pridonijeti rastu njihove socijalne i opće psihofizičke otpornosti na razne vrste stresa, rizikâ i ugroza (Wernesjö, 2012; Thatun i Heissler, 2013; Smyth, Shannon i Dolan, 2015). Primjerice ako se na dječje migrantsko iskustvo iz psihijatrijske i medicinske perspektive gleda kao na isključivo traumatski čin, izostaje razumijevanje njihovih strategija nošenja sa životnim izazovima, njihove otpornosti i adaptabilnog potencijala, upozorava Wernesjö (2012). Autor također ističe kako su potrebna istraživanja koja se bave »strukturnim uvjetima i procesima moći, rasizma i društvenog isključivanja u zemljama primitka te kako ti faktori mogu utjecati na dobrobit i životne situacije maloljetnih tražitelja azila bez pratnje« (Wernesjö, 2012: 505). To postaje jednako važnom istraživačkom temom u mnogim aspektima javnog života i društvenih odnosa unutar zajednice, ali i institucija, pa tako i odgojno-obrazovnih, u kojima strani maloljetnici ostvaruju interakcije i odnose sa širim društvom primitka. 
Koncept "postmigracijske ekologije« omogućuje sagledavanje i analizu obrazovnih politika i mjera spram djece migranata u postmigracijskoj fazi njihova putovanja, upravo zato što fokus usmjeruje na društveno-politički kontekst, $\mathrm{tj}$. na strukturne preduvjete obrazovanja i aktivnosti u obrazovnim ustanovama usmjerenim na te učenike (Nillson i Bunar, 2015: 3). Na tragu tog pristupa i mi u ovom radu analiziramo prije svega strukturne uvjete i jamstva za uključivanje stranih maloljetnika bez pratnje $\mathrm{u}$ formalni obrazovni proces, ali i u neformalne programe poučavanja i socijalizacije (npr. učenje jezika za djecu i odrasle). Pritom nas više zanimaju kontekstualni (pravni i organizacijski) aspekti toga procesa (tj. odgovori državnog sustava na prihvat i školovanje djece izbjeglica) nego sadržajni (kurikularni i pedagoško-didaktički) aspekti odgojno-obrazovnog sustava. Smatramo kako pravna jamstva i obrazovni proces tako mogu poslužiti kao preduvjet prvotne integracije stranih maloljetnika bez pratnje, dok izostanak tih jamstava te neadekvatna implementacija obrazovnih politika vode isključivanju, diskriminaciji i neintegraciji stranih maloljetnika bez pratnje unutar širih društvenih tokova.

Složena problematika jezične prilagodbe te obrazovne integracije stranih maloljetnika bez pratnje u Hrvatskoj nije do sada bila glavnim predmetom istraživanjâ, dok s druge strane postoje istraživanja koja propituju opće statusno-pravne aspekte zaštite djece bez pratnje u Hrvatskoj (Jelavić, 2008; Kraljević, Marinović i Žigante Živković, 2011; Korać Graovac, 2014). Domaća su izvješća (Bužinkić i Kranjec, 2012; Kuti, 2014) upozorila na niz propusta i izazova koji se tiču integracije izbjeglica i općenito stranaca u hrvatsko društvo. Rezultati istraživanja Migrant Integration Policy Index - MIPEX Croatia pokazali su kako se opći zakonski okvir za integraciju stranaca u Hrvatskoj poboljšao paralelno s procesom harmonizacije hrvatskog zakonodavstva s acquisom EU-a, posebice netom prije pridruživanja Hrvatske Europskoj uniji. Iako se stranci u Hrvatskoj susreću s tek polovično povoljnim integracijskim politikama provedbe standarda Europske unije, mjere integracije često mogu biti narušene diskrecijskim postupcima hrvatskih vlasti (Vankova i sur., 2014: 2). Od sedam istraženih dimenzija integracije upravo je područje obrazovanja stranaca $\mathrm{u}$ RH ocijenjeno najnižom ocjenom (13/100), kao izrazito nepovoljno.

Premda je posljednjih godina u procesu skrbi za strane maloljetnike bez pratnje u svim segmentima napravljen značajan pomak, moglo bi se reći da on u segmentu učenja jezika i uključivanja u obrazovni sustav nije na istoj razini s ostalim segmentima skrbi, unatoč naporima i približavanju standardima njihova prihvata, zaštite i integracije, sukladno načelu najboljeg inte- 
resa djeteta i smjernicama Akcijskog plana EU za maloljetnike bez pratnje (2010 - 2014.) (prema Marušić, 2014: 46). Naime pri individualnoj procjeni »najboljeg interesa djeteta ${ }^{8}{ }^{8}$ i njegovih prava na internacionalnoj se razini sustavno propituje taj interes u ovisnosti o cjelokupnoj perspektivi djeteta, specifičnostima njegova kulturnog nasljeđa, šansama za povratak i sl. (Bhabha, 2004: 146; Bartholet, 2004: 26). Stoga se primarno ulažu institucionalni napori u omogućivanje da djeca odrastaju u zemlji porijekla, a tek sekundarno u lokalnu integraciju, iako je to u slučaju djece izbjeglica bez pratnje češća potreba. Time integracija u šire društvo, koja je posredovana učenjem jezika i funkcionalnim uključivanjem u obrazovni sustav društva primitka, treba postati jednom od prioritetnih politika i mjera za strane maloljetnike bez pratnje.

Slično tomu upravo su učenje hrvatskog jezika i uključivanje u obrazovni sustav jedna od najvažnijih dimenzija integracije, što se dosad otežano provodilo kako za populaciju odraslih izbjeglica tako i za djecu izbjeglice i maloljetne strance bez pratnje (iako im je svima to pravo zakonski zajamčeno). Pa ipak, budući da nema podrobnijih istraživanja na tu specifičnu temu, odlučili smo istražiti tu problematiku u kontekstu hrvatskoga obrazovnog sustava i općenitije u kontekstu hrvatskoga društva.

\section{BROJ STRANIH MALOLJETNIKA BEZ PRATNJE U HRVATSKOJ: TRENDOVI I STATISTIKA}

Što o prisutnosti stranih maloljetnika bez pratnje u hrvatskom društvu govore brojevi? Posljednjih nekoliko godina u Hrvatskoj se značajno povećao broj stranih maloljetnika bez pratnje, s vrhuncem trenda u 2011. i 2012. godini (tablica 1). Prema podacima Ministarstva unutarnjih poslova, od 2006. do kraja srpnja 2014. u Hrvatsku je došlo ukupno 3255 stranih maloljetnika bez pratnje, od čega oko četiristo maloljetnih tražitelja azila bez pratnje, najviše državljana iz konfliktnih ili ratnih zona: Afganistana $(72 \%)$, Pakistana (7\%), Somalije (6\%), Sirije (2\%) i Alžira (2\%) (MUP, 2015). Oba broja predstavljaju oko deset posto ukupne populacije nezakonitih migranata te nešto veći udio unutar populacije tražitelja azila u RH, što je potvrdilo i istraživanje UNHCR-a iz 2011. (Kraljević, Marinović i Žigante Živković, 2011: 8). Takvo povećanje u posljednjoj dekadi, s maksimumom između deset i petnaest posto u ukupnom udjelu tražitelja azila, odgovara

8 Načelo Best Interest of the Child, prema definiciji UNHCR-a, najšire se tumači kao dobrobit djeteta. Upravo to načelo najčešće se postavlja kao determinirajuća odrednica za postupanja poput posvajanja (čl. 21) ili čak odvajanja djeteta od roditelja protiv njihove volje (čl. 9). Vidi: UNHCR (2008: 14). 
trendovima i u ostalim državama Europske unije i zapadnih demokracija uopće (Bhabha, 2004: 142). Do kraja srpnja 2014. odobreno je jedanaest statusa zaštite stranim maloljetnicima bez pratnje, a u više od $80 \%$ slučajeva postupak je obustavljen (MUP, 2014). U više od 95\% zabilježenih slučajeva riječ je o muškoj populaciji u dobi od šesnaest i sedamnaest godina, koji dakle pripadaju zakonskoj kategoriji tzv. »starijih maloljetnika«.

Tablica 1. Broj stranih maloljetnika bez pratnje u Hrvatskoj 2006. - 2014.

Table 1. Number of foreign unaccompanied minors in Croatia, 2006-2014

\begin{tabular}{|c|c|c|c|}
\hline Godina & $\begin{array}{c}\text { Ukupni broj stranih } \\
\text { maloljetnika } \mathbf{u} \\
\text { statusu »nezakonitog } \\
\text { migranta« }\end{array}$ & $\begin{array}{l}\text { Ukupni broj stranih } \\
\text { maloljetnika bez } \\
\text { pratnje u statusu } \\
\text { »nezakonitog } \\
\text { migranta« }\end{array}$ & $\begin{array}{c}\text { Ukupni broj } \\
\text { maloljetnih tražitelja } \\
\text { azila bez pratnje }\end{array}$ \\
\hline 2006. & 663 & 562 & - \\
\hline 2007. & 612 & 547 & 10 \\
\hline 2008. & 173 & 128 & 4 \\
\hline 2009. & 166 & 103 & 21 \\
\hline 2010. & 271 & 172 & 38 \\
\hline 2011. & 811 & 552 & 197 \\
\hline 2012. & 1167 & 726 & 70 \\
\hline 2013. & 465 & 302 & 55 \\
\hline 2014. & $\begin{array}{c}182 \\
\text { (do 31. srpnja) }\end{array}$ & $\begin{array}{c}163 \\
\text { (do 31. srpnja) }\end{array}$ & $\begin{array}{c}10 \\
\text { (do 31. prosinca) }\end{array}$ \\
\hline Ukupno & 4510 & 3255 & 405 \\
\hline
\end{tabular}

Izvor: MUP (2014), MUP (2015) - prilagodba autorâ.

U kontekstu aktualne humanitarne krize vezane uz tokove izbjeglica $\mathrm{i}$ drugih prisilnih migranata koji tijekom 2015. pristižu u europske zemlje putem Istočnomediteranske i Balkanske rute i broj se maloljetnika bez pratnje u tim tokovima povećao u odnosu na 2014. Prema podacima UNHCR-a, na dan 31. prosinca 2015. u Europu je tim rutama ušlo više od milijun izbjeglica i migranata, od čega $82 \%$ morskim putem preko Turske u Grčku i dalje Balkanskom rutom, preko Makedonije i Srbije, u Hrvatsku, Sloveniju pa u 
Austriju i Njemačku. ${ }^{9}$ Procjene govore o oko dvadeset posto djece koja se kreću u tom izbjegličkom i migrantskom toku te postoje indicije, sukladno podacima UNICEF-a, kako se broj djece tražitelja azila u 2015. povećao dvostruko u usporedbi s $2014 .{ }^{10}$ Podaci o broju djece bez pratnje ipak nisu precizni, no primjerice izvješće UNHCR-a upozorava kako se broj djece bez pratnje i djece odvojene od roditelja povećao, posebice državljana Sirije, Afganistana i Eritreje (UNHCR, 2015).

U RH je od početka dolaska izbjeglica Balkanskom rutom 16. rujna pa sve do 31. prosinca 2015. ušlo, i kroz nju prošlo, više od 555.000 prisilnih migranata. ${ }^{11}$ Nepostojanje precizne statistike broja stranih maloljetnika bez pratnje kao sudionika recentnih tokova prisilnih migranata u današnjoj situaciji glavni je metodološki problem budućih istraživanja. ${ }^{12}$ Ipak, u ovom istraživanju naš je fokus bio ponajprije na brojnosti i položaju stranih maloljetnika bez pratnje koji su u Hrvatsku došli do srpnja 2014., dakle prije početka aktualne humanitarne krize vezane uz izbjegličke tokove kojima danas svjedočimo, te je naša analiza prilagođena upravo toj činjenici. Stoga u nastavku analiziramo opća pravna pitanja u vezi s položajem stranih maloljetnika bez pratnje kao strukturne preduvjete za njihovo uključivanje u obrazovni proces.

$9 \quad$ Vidi: http://data.unhcr.org/mediterranean/regional.php. Na dan 16. rujna 2015. zbog zatvaranja mađarske granice žicom došlo je do skretanja rute izbjeglica i drugih prisilnih migranata u Hrvatsku.

10 Vidi: http://www.unicef.hr/show.jsp?newscontainer=201673\&page=146930\&singlenew sid=201685 (30. 01. 2016.). U 2014. dolazak izbjeglica i migranata odvijao se uglavnom preko Srednjomediteranske rute, od obala Libije i Tunisa preko Sredozemlja do Malte i Lampeduse, tj. Italije.

11 Isprva su prihvat i smještaj za izbjeglice bili osigurani u prihvatnom kampu Opatovac u pograničnom području nedaleko od granice s Republikom Srbijom, da bi se 3. studenoga otvorio zimski prihvatni tranzitni kamp kod Slavonskog Broda. S obzirom na dinamiku i opseg migrantskog toka, koji je u pojedinim danima značio i dolazak oko 10.000 ljudi, a kapacitet kampa bio je 5000 mjesta, događale su se i situacije kratkoročnog odvajanja obitelji, koje bi se ponovno spajale $u$ za to predviđenim službama nakon registracije $u$ kampu. Danas su te situacije sve rjeđe zbog bolje organizacije te bržeg transfera, prihvata i daljnjeg tranzita. Vidi više na http://www.mup.hr/228684.aspx i Institut za migracije i narodnosti (2015).

12 Za neke indicije vidi: www.jutarnji.hr/pokusavaju-pobjeci--ne-razumiju-jezik-ni-zakone-a-zele-samo-jedno---stici-u-europu/1495848/ (31. 01. 2016.). 


\section{OPĆA STATUSNO-PRAVNA PITANJA U VEZI S POLOŽAJEM STRANIH MALOLJETNIKA BEZ PRATNJE I KOMUNIKACIJA S INSTITUCIJAMA}

Primarne politike i mjere po dolasku stranih maloljetnika bez pratnje na teritorij Republike Hrvatske usmjerene su identifikaciji, skrbi i zaštiti te se ponajprije odnose na državne mehanizme u domeni utvrđivanja identiteta i dobi maloljetnika (inicijalnim razgovorom uz prevoditelja). Po dodjeljivanju posebnog skrbnika ${ }^{13}$ maloljetna se osoba registrira u ustanovu (najčešće dječji domovi u sustavu nadležnog centra za socijalnu skrb). Tamo im se osigurava smještaj i jamče sloboda kretanja te pružanje pravne i financijske podrške. U kasnijoj fazi moguće je i pokretanje procedure njihove reunifikacije s obitelji, poštujući načelo najboljeg interesa djeteta. Postojanje skrbnika te pravo na spajanje obitelji, uz slobodu kretanja, bitne su odrednice koje status stranih maloljetnika bez pratnje čine poželjnijim od statusa odraslih »nezakonitih migranata $u \mathrm{u}$ istom položaju.

Kako su potvrdili i naši sugovornici (DODM i CZSS), ako se sumnja u točnu dob osobe, a nije moguće drugim putevima doći do potvrde maloljetništva, u obzir se uzima i izjava osobe kojom se ona deklarira maloljetnom. No vlastita izjava o maloljetničkom statusu neregularnog migranta ponekad je diskutabilna jer »maloljetnici« smatraju da njome mogu zadobiti povlašteni položaj, koji bi im prije svega omogućio slobodu kretanja smještanjem u domove za djecu. S obzirom na prezentiranu statistiku o broju starijih maloljetnika utvrđivanje njihove dobi vrlo je čest problem. Također, UNHCR navodi da je sustav kojim institucije u RH koje se bave stranim maloljetnicima prikupljaju i operacionaliziraju statističke podatke o njima neujednačen, što pridonosi i slaboj vidljivosti potreba te djece, čime je ujedno jedno od ishodišta nerješavanja njihovih problema.

Ograničavanje kretanja djeteta smještanjem u ustanove zatvorenog tipa samo se iznimno primjenjuje, najčešće kada je riječ o smještaju s ostalim članovima obitelji, primjerice u prihvatnome (detencijskom) centru za nezakonite migrante. No takva praksa osim kršenja odredbi Deklaracije o pravima djeteta može biti snažan psihofizički stres za ionako traumatizirano dijete, koje bi tamo moglo biti dodatno odvojeno od poznatih mu osoba, ali i podložno novom zanemarivanju, traumama i nasilju (ICRC, 2014: 4, 12; MSPM). Rješavanje spomenutih pitanja možemo ubrojiti u prioritetne aktivnosti za osiguranje egzistencijalnih potreba, nužnih za što hitnije temeljno fizičko, tj.

U skladu s čl. 167. st. 5. Obiteljskog zakona, NN 116/03, 17/04, 136/04, 107/7, 57/11, 61/11, 25/13. 
stambeno zbrinjavanje, ali odmah potom i osiguranje materijalne i psihosocijalne skrbi te daljnji stručni rad s maloljetnikom. ${ }^{14}$

U tom se procesu akteri u sustavu brige i skrbi inicijalno suočavaju s velikim izazovom i problemom komunikacije sa stranim maloljetnicima bez pratnje (Babić, 2014: 148-149; OCD), kojima je po njihovu dolasku u RH u praksi najčešće zajamčena mogućnost komuniciranja na engleskom i eventualno francuskom jeziku. Sporazumijevanje na drugim jezicima zajamčeno je uz pomoć službenih prevoditelja (primjerice na nekim azijskim jezicima - farsi, urdu i arapski), ali većinom po izražavanju namjere, tj. tek po pokretanju procedure za priznavanje statusa azila, što potvrđuju i riječi našeg sugovornika iz organizacije koja aktivno skrbi za maloljetne tražitelje azila bez pratnje u RH:

Što se jezika tiče, govore se razni. Ministarstvo unutrašnjih poslova izdvaja sredstva za usluge prevoditelja, ali mi nemamo sredstava za tu namjenu, pa to ponekad predstavlja veliki problem. U svakoj situaciji ja pronađem nekoga tko govori engleski. Primjerice i maloljetnici iz Afganistana govore dobar engleski, kojeg su naučili na putu do ovdje jer su vlastitim obiteljima služili kao prevoditelji. (...) za pomoć u prevođenju s jezika koji nisu engleski ili talijanski koristimo se prijateljima koji poznaju farsi, arapski ili njemački. (HCK)

Kao i u slučaju odraslih osoba i ovdje se javlja problem s prevoditeljima i prevoditeljicama koji bi trebali biti istoga spola kao i maloljetni tražitelj ili tražiteljica azila (MUP). Ako komunikacija s predstavnicima institucija nije na engleskome, bitno je otežana, u nekim uvjetima čak i nemoguća. Time se, osim odvojenosti od obitelji, strani maloljetnici bez pratnje zatječu u kulturno i jezično stranoj okolini. Organizacije civilnog društva na sebe su preuzele zadatak sastavljanja liste prevoditelja za različite jezike kao doprinos Vladinim tijelima u organizaciji tog segmenta skrbi o stranim maloljetnicima (OCD).

Pitanje problematike jezika zrcali se i u jednome drugom problemu koji se tiče načina dodjele posebnog skrbnika stranome maloljetniku bez pratnje u statusu nezakonitog migranta. ${ }^{15} \mathrm{U}$ nekolicini slučajeva tog je skrbnika

14 Sustav socijalne skrbi intenzivnije se uključio u rješavanje ovog problema na inicijativu mreže nacionalnih partnera poput Ureda UNHCR-a u Hrvatskoj i nevladine organizacije Spasimo djecu 1997. provođenjem projekta »Djeca odvojena od roditelja «, a Udruga za inicijative u socijalnoj politici 2001. uspostavila je Koordinaciju za praćenje stanja djece izvan zemlje podrijetla (Jelavić, 2008; Kraljević, Marinović i Žigante Živković, 2011: 17). Ured pravobraniteljice za djecu pokrenuo je i edukativne radionice za uspostavljanje standarda u postupanju prema djeci bez pratnje (Jelavić, 2008; Marušić, 2014: 41).

15 Prema Protokolu, "posebni skrbnik - je osoba koju imenuje centar za socijalnu skrb radi zaštite pojedinih osobnih i imovinskih prava djeteta bez pratnje«, a koji se izabire s »liste posebnih skrbnika« koju čini »popis educiranih osoba utvrđen od ministarstva nadležnog 
imenovao Centar za socijalnu skrb, ali bilo je i slučajeva da se skrbnikom imenuje osoba koja je stranac unutar same grupe neregularnih migranata među kojima su putovali i strani maloljetnici bez pratnje (CZSS). Nedosljednost u regulativama i disfunkcionalnost postojećeg okvira skrbi o stranim maloljetnicima bez pratnje nisu samo materijalno uvjetovane, premda je i to bitan razlog (CZSS, MUP, MSPM).

Važan je problem i to što, iako su posebni skrbnici i drugi stručnjaci koji rade s djecom bez pratnje (policijski službenici, socijalni radnici, zdravstveni radnici i predstavnici organizacija civilnog društva) obvezni sudjelovati $\mathrm{u}$ sustavnim edukacijama i osposobljavanju za rad s djecom bez pratnje, $\mathrm{u}$ cilju stjecanja specifičnih pedagoških vještina i kompetencija za rad s djecom bez pratnje, dosad nadležno ministarstvo nije organiziralo takvu edukaciju. Ne postoje ni specijalizirane radionice i programi koji bi bili namijenjeni isključivo za edukaciju posebnih skrbnika za rad sa stranim maloljetnicima bez pratnje (DODM, CZSS, OCD, MUP, OŠ, SŠ; Babić, 2014: 150). Kuriozitet je da čak i neki vrlo važni dionici odnosno kreatori politika unutar tog sustava ni sami nisu upoznati s trenutačnim pravnim obvezama u pogledu osiguravanja učenja hrvatskoga jezika i omogućivanja obrazovanja, pa kažu da bi takve obveze tek trebalo uvesti u sustav, što potvrđuju naši sugovornici (DODM, OCD).

\section{PROBLEMATIKA UČENJA JEZIKA I OBRAZOVANJA STRANIH MALOLJETNIKA BEZ PRATNJE}

\section{Pravni okvir i zajamčenost prava na obrazovanje i učenje jezika}

Pravni okvir zajamčenosti učenja jezika i obrazovanja stranih maloljetnika bez pratnje određen je Konvencijom o pravima djeteta UN-a iz 1989. (Convention on the Rights of the Child). Njome se (čl. 28) propisuje kako djeci treba osigurati realizaciju prava na obrazovanje kao takvo da bi mogla $\mathrm{u}$ potpunosti razviti vlastitu osobnost, talente, mentalne i fizičke sposobnosti te promovirati mir i međusobnu toleranciju (čl. 29). Obrazovanje je jedno od temeljnih zajamčenih prava spomenute Konvencije, ali i Konvencije o statusu izbjeglica iz $1951 .{ }^{16}$, prije svega stoga što omogućuje stjecanje vještina i kompetencija za zapošljavanje kao i stjecanje vještina koje omogućuju uključivanje pojedinaca u društvo (Ager i Strang, 2008).

za poslove socijalne skrbi koje mogu biti imenovane za posebnog skrbnika djetetu bez pratnje« (Vlada RH, 2013: 2).

16 Konvencija o statusu izbjeglica, UNTS 189, 28. srpnja 1951.; SL SFRJ: MU 15/1960. 
Brown (2001, prema Ting, 2014: 8) ustvrđuje tri ključne koristi od dobro provedene edukacije: 1) psihološka korist, odnosno distrakcija djece traumatizirane nasiljem ili samo promjenom boravišta i/ili odvajanjem od obitelji; 2) stjecanje znanja i vještina koje pridonose razvoju djeteta u produktivnoga, tolerantnoga i miroljubivoga građanina; 3) zaštita i prevencija od devijantnog ponašanja, prije svega stoga što je psihološki status djece izuzetno važan za njihovo tjelesno zdravlje. Djecu koja su doživjela traumu ili žive pod velikim stresom obično neće biti lako angažirati za društveno prihvatljive aktivnosti, i upravo je tu uloga obrazovnih institucija da pomognu u prevladavanju te traume i razvoju svih potencijala djeteta. Na koji način hrvatski obrazovni sustav strukturno odgovara na taj izazov u postmigracijskoj fazi iskustva stranog učenika?

Pitanje učenja jezika, tj. nepostojanja sustavno provođenog i od države financiranog programa poučavanja hrvatskog jezika (od jeseni 2011.), bilo je jednako aktualno i relevantno za strane maloljetnike bez pratnje kao i za populaciju odraslih osoba pod zaštitom u Hrvatskoj. Iako su Zakonom o odgoju i obrazovanju u osnovnoj i srednjoj školi (čl. 46), a također i Zakonom o strancima i Zakonom o međunarodnoj i privremenoj zaštiti (čl. 32) ${ }^{17}$ te Protokolom i Pravilnikom ${ }^{18}$ zajamčeni školovanje i učenje jezika za strane maloljetnike bez pratnje, u praksi se to rijetko ostvaruje. Prvenstveni kriterij pristupa obrazovanju za strane maloljetnike bez pratnje jest njihov pravni status (Nonchev i Tagarov, 2012: 18). Dok je taj pristup zajamčen za djecu izbjeglice i djecu tražitelje zaštite, izvještaj MIPEX navodi da su tek izmjene Zakona o odgoju i obrazovanju u osnovnoj i srednjoj školi (15. srpnja 2013.) omogućile određeni ograničeni pristup obrazovanju za nezakonite migrante. Djeci stranaca koji nezakonito borave u Hrvatskoj omogućen je pristup osnovnom obrazovanju, dok se ne mogu upisati u srednju školu, niti imaju

17 Članak 58. (Obrazovanje): »(1) Pravo na osnovno i srednje obrazovanje dijete tražitelj ostvaruje pod istim uvjetima kao hrvatski državljanin. (2) Tražitelju, koji je započeo ostvarivati pravo na srednjoškolsko obrazovanje iz stavka 1. ovoga članka, omogućit će se nastavak srednjoškolskog obrazovanja i nakon stjecanja punoljetnosti. (3) Ostvarivanje prava iz stavka 1. ovoga članka omogućit će se djetetu tražitelju u roku od 30 dana od dana podnošenja zahtjeva do izvršenja odluke o povratku. (4) Ako dijete tražitelj ne zna ili nedovoljno poznaje hrvatski jezik, omogućit će mu se pohađanje pripremne nastave ili dopunske nastave hrvatskog jezika, kao i dopunske nastave u pojedinim nastavnim predmetima, ako za to postoji potreba.«

18 Iz projekta »Strategije učenja i poučavanja hrvatskoga kao inoga jezika« proistekla je publikacija Inojezični učenik u okruženju hrvatskoga jezika (Češi, Cvikić i Milović, 2012). Osim toga Ministarstvo znanosti, obrazovanja i sporta donosi svojevrsni »pravilnik « koji uređuje provođenje nastave za inojezične učenike (MZOS, 2013). Na sličnom su tragu i preporuke u vezi s obrazovanjem djece migrantskog porijekla (SIRIUS, 2013). 
pristup visokoškolskom obrazovanju ili stručnom osposobljavanju (MIPEX, 2014: 18). ${ }^{19}$

K tomu, učenje hrvatskoga jezika za osobe pod zaštitom (tražitelje azila, azilante i strance pod supsidijarnom zaštitom) starije od petnaest godina radi pristupa srednjoškolskome obrazovnom sustavu također je zajamčeno, ali se u praksi rijetko ostvaruje. Prema tom bi se zajamčenom pravu učenje hrvatskoga jezika za osobe pod zaštitom koje se ne uključuju u obrazovni sustav trebalo organizirati pri pučkim otvorenim učilištima i drugima ustanovama koje imaju odobrenje za izvođenje programa osnovnog obrazovanja odraslih starijih od petnaest godina. Za ostale skupine stranaca tečajevi se organiziraju u Croaticumu - Centru za hrvatski kao drugi i strani jezik na Odsjeku za kroatistiku Filozofskoga fakulteta u Zagrebu, koji izvodi nastavne programe te održava ispite poznavanja hrvatskoga jezika za neizvorne govornike. Iako je od prosinca 2014. na snazi novi »Program učenja hrvatskog jezika, povijesti i kulture za azilante i strance pod supsidijarnom zaštitom radi uključivanja u hrvatsko društvo«, činjenica je da se on nije provodio od jeseni 2011. do ljeta 2015., kada se počeo izvoditi za populaciju priznatih izbjeglica (azilanata) i osoba pod supsidijarnom zaštitom, uglavnom onih starijih od petnaest godina, iako među njima rijetko i onih starijih stranih maloljetnika bez pratnje.

Čl. 74 Zakona o međunarodnoj i privremenoj zaštiti restriktivno se odnosi prema azilantima i stranim državljanima pod supsidijarnom zaštitom, koji imaju obvezu da redovito pohađaju obvezni tečaj hrvatskog jezika, a ako to ne čine, obvezni su nadoknaditi utrošena financijska sredstva, tj. podmiriti troškove tečaja. Vrsta je to penalizacije dosadašnjih korisnika sustava koji ne ispunjavaju svoje zakonske obveze, suprotna Direktivama Vijeća Europe, kao što je komentirajući prijašnju verziju tog zakona (Zakon o azilu), iz kojeg i dolazi ta odredba, primijetila Zdravković (2011: 11).

U studenome 2011. prihvaćen je »Program hrvatskoga jezika za pripremnu nastavu za učenike osnovne i srednje škole koji ne znaju ili nedovoljno poznaju hrvatski jezik «, koji je predviđen u trajanju od maksimalno sedamdeset sati poučavanja hrvatskog jezika tijekom jedne nastavne godine (HPC, 2012: 11; MZOS, 2011). Za maloljetne tražitelje azila pravo na osnovno i srednje obrazovanje omogućit će se djetetu tražitelju zaštite u roku od

19 Dodatni zaključak istraživanja o zakonskoj zajamčenosti politika integracije za imigrante u obrazovnom sustavu RH bio je: »...od hrvatskih se škola zahtijeva pružanje vrlo malo integracijskih mjera za migrantske učenike, kao i u većini balkanskih zemalja. Djeca migranata mogu imati koristi od službene potpore učenja hrvatskog jezika u osnovnom i srednjoškolskom obrazovanju, ali im nije omogućeno učenje materinskog jezika.« (Vankova i sur., 2014: 18). 
trideset dana od dana podnošenja zahtjeva do izvršenja odluke o povratku (čl. 58 Zakona o međunarodnoj i privremenoj zaštiti). Ako se evaluacijom stručnih službi utvrdi da je stupanj poznavanja hrvatskog jezika nedovoljan za pohađanje redovite nastave, kao preduvjet za savladavanje osnovnoškolskog ili srednjoškolskog programa ponuđena je mogućnost dodatnih intenzivnih tečajeva hrvatskog jezika kroz pripremne ili dodatne, tj. dopunske sate hrvatskog jezika, kao i dopunske nastave u pojedinim nastavnim predmetima ako za to postoji potreba. ${ }^{20}$

Područje učenja jezika i obrazovanja prepoznato je kao jedna od dimenzija integracije na kojoj država želi aktivno raditi kako bi ispravila nedostatke i propuste odgojno-obrazovnog sustava spram djece tražitelja azila i djece izbjeglica. ${ }^{21}$ No rezultati našeg istraživanja upućuju na jaz između razine normativne zakonske zajamčenosti prava na učenje jezika i obrazovanje, tj. obrazovnih politika na nacionalnoj razini i praktičnih lokalnih rješenja sustava s obzirom na specifične potrebe proučavane populacije.

\section{Implementacijska razina - poučavanje jezika i uključivanje stranih maloljetnika bez pratnje u obrazovni sustav}

Već je naglašeno kako od jeseni 2011. pa do ljeta 2015. nije bilo sustavno provođenog i od države financiranog programa poučavanja hrvatskog jezika. Suplementarne programe učenja jezika za odrasle tražitelje zaštite pružaju djelatnici Crvenoga križa u Prihvatilištu u Kutini i Prihvatilištu u Dugavama te druge organizacije civilnog društva poput Centra za mirovne studije, kao i neke humanitarno-vjerske organizacije (Isusovačka služba za izbjeglice ili Luteranska crkva u Kutini). Istraživanje je potvrdilo kako su ti tečajevi dosad bili na dobrovoljnoj bazi, organizirani putem mreže volontera koji su ih provodili jednom do dvaput tjedno u prostorima obaju prihvatilišta za tražitelje azila ili u prostorijama navedenih civilnih organizacija i kutinske vjerske ustanove. Tečajevi su jednako bili namijenjeni za tražitelje

20 Usporedbe radi: u Švedskoj, koja ima znatno dužu tradiciju useljavanja od Hrvatske, ne postoje propisi na nacionalnoj razini koji određuju kako obrazovanje učenika migrantskog porijekla treba biti organizirano. Nilsson i Bunar (2015: 7) smatraju da je moguće objašnjenje za to »idologijsko vjerovanje« kako će se djeca stranog porijekla koja se useljavaju i ulaze u švedski obrazovni sustav lako uklopiti u nacionalni školski, društveni i pedagoški kontekst akulturacijom. Autori se u istraživanju usredotočuju na obrazovanje nedokumentirane djece, djece koja su tražitelji azila, djece izbjeglica te djece imigrantskih radnika u švedskome nacionalnom obrazovnom sustavu.

${ }^{21}$ Vidi više u mjerama Ureda za ljudska prava i prava nacionalnih manjina Vlade RH definiranim u strateškom dokumentu »Akcijski plan za uklanjanje prepreka u ostvarivanju pojedinih prava u području integracije stranaca u hrvatsko društvo, za razdoblje od 2013. do 2015. godine $\ll$. 
zaštite kao i za priznate izbjeglice (vjerska ustanova, HCK), a ponekad su kombinirani i s poučavanjem drugih sadržaja, poput engleskog jezika.

Najčešće su ti tečajevi strukturirani tako da prate službeni program Croaticuma kao edukacijskog centra licenciranog za izvođenje službenog programa učenja hrvatskog jezika za neizvorne, tj. strane govornike (OCD i HCK), dok se, recimo u slučaju Luteranske crkve, budući da je riječ o vjerskoj ustanovi, ne drže striktno formalnog programa. U tim tečajevima jezika ponekad, iako rijetko, sudjeluju i strani maloljetnici bez pratnje. Tečajevi su istovremeno i proces socijalizacije, upoznavanja polaznika s hrvatskom kulturom, društvom i nekim specifičnostima svakodnevnoga javnog ophođenja. Oni su i jedan od početnih orijentira za snalaženje u polju birokratskih procedura te dijelom i oblik savjetovanja o pravnim pitanjima u vezi s ostvarenjem prava i obveza. U Crvenom križu posebno se poučava i priprema strane maloljetnike bez pratnje na tečaju koji je pripremna faza uoči polaska u školu, no poučavatelji tog tečaja nisu licencirani učitelji hrvatskog jezika, već se poučavanje temelji na neformalnome volonterskom radu (OCD). Ponekad tečajevi jezika odgovaraju i na druge potrebe samih maloljetnika, kao i odraslih tražitelja azila, koje se ne tiču samo pitanja usvajanja jezika i školskoga gradiva već i općenitijih statusno-pravnih problema.

Mi obrazovanje radimo i kroz tečaj jezika... Ne možemo reći da je to posebno za maloljetnike bez pratnje, iako za neke od njih znamo da su maloljetnici bez pratnje, ali za neke od njih ne znamo (...) tečaj jezika nije usmjeren isključivo na jezik. Tijekom lekcija (...) ako imaju dodatnih pitanja, imamo odvjetnika ovdje i neke druge ljude koji imaju neke veze i mogu pomoći u rješavanju različitih situacija. Neki od njih žele pokrenuti postupak spajanja s obitelji, radimo savjetovanje za njih, ali ne uključujemo se u proceduru. (OCD)

Kakva je situacija s ostvarenjem prava na obrazovanje stranih maloljetnika bez pratnje? Iako je i sadašnjim važećim Zakonom te Protokolom zajamčen pristup obrazovanju kao i drugim sadržajima u cilju integracije, to se pravo u praksi vrlo rijetko primjenjuje. Glavni je razlog duljina boravka maloljetnih stranaca bez pratnje u zemlji. Uočljiv je fenomen da se u institucijama kojima su povjereni na skrb oni zadržavaju kratko te ih samovoljno napuštaju unutar svega nekoliko tjedana od dana dolaska, u čak više od osamdeset posto slučajeva (DODM, MUP, UNHCR). U praksi se pokazalo da se strani maloljetnici bez pratnje zadržavaju u Hrvatskoj prekratko da bi se uopće počelo s ostvarivanjem zajamčenih prava. No čak i za one koji se zadrže relativno duže, pa i za stalno, njihova zajamčena prava tek su polovično ostvariva u praksi. Problem znatnijeg raskoraka između propisane 
pravne regulative $u$ području obrazovanja i preporučenih dobrih praksi s jedne te praksa u svakodnevici s druge strane uočljiv je i u nekim susjednim zemljama, primjerice Sloveniji (Gornik, 2009: 133), na što također upućuju i rezultati usporedbe država u hrvatskom okružju, iz istraživanja MIPEX (Vankova i sur., 2014).

Za uspješno uključivanje u odgojno-obrazovni sustav učenik treba proći provjeru znanja hrvatskoga jezika, koju provodi stručno tijelo pripadajuće obrazovne ustanove. Potom se učenik uključuje u odgovarajuću vrstu i razinu obrazovanja u obrazovnoj ustanovi koja je najbliža boravištu učenika. ${ }^{22}$ Ovisno o učenikovoj dobi obrazovna ustanova procjenjuje hoće li učenik biti paralelno uključen u pohađanje odgovarajućega ili približno odgovarajućega razreda. Ako se učenik uključi paralelno u nastavu, njegovo pohađanje ne vrednuje se ocjenom, već samo praćenjem u smislu socijalizacije i pripremnog učenja jezika (SŠ). U praksi, radi učinkovite integracije učenika škole češće organiziraju individualne (mentorske) nego skupne oblike neposrednoga odgojno-obrazovnog rada. Njima se učenicima omogućuje učinkovito svladavanje hrvatskoga jezika i nadoknađuje nedovoljno znanje u pojedinim nastavnim predmetima (MZOS, 2013; uz potvrdu sugovornikâ iz OCD-a, kulturne ustanove i SŠ). O tome svjedoče i riječi jednog sugovornika:

Ove smo godine imali slučaj stranca iz Turske koji je trebao pomoć u učenju iz fizike i matematike, pa smo angažirali profesora, koji je ustanovio da je dječakov problem zapravo neadekvatno poznavanje hrvatskog jezika pa stoga nije uspijevao ni shvatiti, a potom niti riješiti zadatke. Taj se profesor dodatno angažirao $i$ saznao da je Ministarstvo obrazovanja proslijedilo naputak spomenutoj školi da (...) organizira dodatne sate poduke iz hrvatskog jezika. No to se nije realiziralo i dječak je gotovo izgubio godinu, premda do toga na kraju nije došlo. Mislim da je profesor sam poduzeo određene radnje, pisao Ministarstou tražeći da na teren izađe Prosvjetna inspekcija i provjeri zbivanja u školi. (OCD)

Iako su sukladno propisima škole dakle obvezne organizirati pohađanje dodatne nastave hrvatskog jezika za strane učenike, ta se mjera vrlo

22 Nameće se i pitanje organizacije zakonom normiranih obrazovnih sadržaja za maloljetne korisnike unutar dodatnog objekta za prihvat stranih maloljetnika bez pratnje, obitelji, žena samaca i drugih ranjivih skupina neregularnih migranata (s ograničenjem kretanja). Takav je objekt upravo u izgradnji unutar prostora Prihvatnog centra za strance u Ježevu, kao ustanovi zatvorenog tipa. Dvojbeno je kako objekt s temeljnom funkcijom detencije i pripreme za deportaciju stranaca iz RH može biti adekvatno mjesto za boravak djece, tj. je li to $\mathrm{u}$ »najboljem interesu djeteta«. Osim toga objekt je daleko od javnog prijevoza, te je pristup najbližim školama ograničen, pa ostaje vidjeti kako će institucije organizirati učenje jezika i pristup obrazovanju za maloljetne strance, unutar same institucije ili na dosad uobičajeni način, njihovim uključivanjem u lokalne škole. 
selektivno provodi, na štetu samih učenika. Naime u praksi je zabilježeno kako se strani maloljetnici bez pratnje obraćaju volonterima poučavateljima s problemima usvajanja ostalih nastavnih predmeta i sadržaja (npr. matematike), ali prije svega zato što ne razumiju jezik kojim se poučava te stoga ne mogu shvatiti ni samo gradivo. MZOS je bio donio odluku i popis od devetnaest osnovnih i dvanaest srednjih škola u Zagrebu u kojima bi se dodatna nastava učenja jezika trebala odvijati (Češi, Cvikić i Milović, 2012). Prema informacijama dobivenim od ispitanika, to se provodi tek $\mathrm{u}$ jednoj od tih dvanaest škola (OCD), zato što trenutačno u ostalim školama nema maloljetnih stranaca polaznika, a i općenito nedostaje specijalizirani kadar za provođenje takve nastave. Dakle i ovdje se zaobilazi odgovornost onih škola koje pohađaju strani maloljetnici bez pratnje za organizaciju takva oblika dodatne nastave, bez obzira na to što postojanje pravnih jamstava nalaže adekvatnu implementaciju obrazovnih politika.

Sukladno odgovorima ispitanika iz nevladina sektora, neke su organizacije civilnog društva samoinicijativno i volonterski preuzele obveze koje bi inače trebao ispunjavati državni sustav školovanja, tj. ustanove odgojno-obrazovnog tipa. Također, ispitanici smatraju kako bi se veća pozornost trebala posvećivati edukaciji samih edukatora, tj. budućih nastavnika uključenih u obrazovni proces (SŠ). To su sadašnji studenti Pravnog fakulteta, tj. Studija socijalnog rada, Edukacijsko-rehabilitacijskog fakulteta, a dijelom i Učiteljskog fakulteta te pedagoških smjerova na studijima hrvatskog jezika.

Također, postavlja se pitanje pružaju li lokalne škole uistinu sustavnu pomoć u dodatnim satima jezika i pomoć u nastavi putem rada asistenata, školskih stručnih službi i slično. Prema iskustvu Srednje tehničke škole iz Kutine, ako je riječ o djetetu iz slavenskoga govornog područja, jezična i nastavna integracija olakšane su samom činjenicom korijenske lingvističke bliskosti jezika (SŠ). Pomaže i to što nastavno osoblje dobro vlada engleskim jezikom, postoji pozitivan radni ambijent te se uz rad stručnih službi (pedagog, psiholog i socijalni radnik) uključivanje u sustav relativno zadovoljavajuće provodi. ${ }^{23}$ Od 2014. vrijedi novi propis po kojemu učenik -

23 U južnoj Australiji škole su uvele integracijske programe, tzv. New Arrivals Program, za djecu imigrante i tražitelje azila, posebno u sredinama u kojima su znatnije zastupljeni (Due i Riggs, 2009: 56), odvajajući ih u posebne razrede, ali ubrzo su uvidjeli propuste i zamke segregacije migranata u posebne obrazovne razrede: slabljenje samopoštovanja učenika, lošiju komunikaciju s izvornim govornicima te manjak intrinzične motivacije i daljnjih izgleda da se okušaju u visokom obrazovanju, što bi i hrvatska praksa svakako trebala nastojati izbjeći (Castro Feinberg, 2000: 220-223). S druge strane, kao primjer dobre prakse ističe se razdvajanje one djece migrantskog porijekla koja govore isti jezik $\mathrm{u}$ odvojene razrede u Britaniji, jer se pokazalo kako se onda više trude i angažiraju u nastavi, a i prisutnost drugih domicilnih učenika u razredu djeluje poticajno na socijalizaciju i školski uspjeh (Sigona i Hughes, 2012: 31-33). 
državljanin treće zemlje, koji dolazi izvan područja EU-a, sam snosi trošak školovanja u iznosu ne manjem od 2500 kn godišnje (MZOS, 2012: čl. 6). Premda, do sada je Školski odbor uz pomoć lokalne (županijske) uprave uglavnom »osiguravao financiranje ili oslobodio učenika plaćanja školarine« (SŠ). Istovremeno, učenici koji nisu hrvatski državljani nemaju pravo na stipendiranje ni na srednjoškolskoj ni na visokoškolskoj, tj. fakultetskoj razini.

Nadalje, organizirano je nekoliko javnih tribina i tematskih večeri upoznavanja s kulturama i zemljama porijekla tražitelja i azilanata na nekoliko lokacija u Kutini i Zagrebu za šire zainteresirano građanstvo u organizaciji knjižnice, OCD-a i HCK-a. Primjeri su to dobrih praksi transkulturne transmisije, suradnje i inkluzije (bilo kroz verbalnu, bilo kroz neverbalnu komunikaciju), razvoja interpersonalnih veza i osnaživanja, ali i učenja jezika kroz različite kreativne formalne i neformalne metode usvajanja znanja, pa čak i zabavu. Glazbeno, likovno, scensko ili plesno izražavanje nadilaze ograničenja koja nameće nepoznavanje jezika (Marsh, 2012: 107-108; HCK). ${ }^{24}$ Voditeljica lokalne knjižnice potvrdila je kako se neformalno učenje jezika odvija i kroz tečajeve i radionice koje su organizirane za same tražitelje i tražiteljice azila (poput radionice slikanja ili primjerice šivanja). No i dalje nema sustavno provođenih i od države organiziranih tečajeva dokvalifikacija i prekvalifikacija, koji bi npr. kombinirali razvoj novih praktičnih vještina s mogućnošću učenja svakodnevnog i stručnog jezika i nazivlja.

Također, već je zamijećen propust da se Protokolom, kao temeljnim dokumentom, obuhvate dvije važne institucije koje su uključene u zaštitu strane maloljetničke populacije, a to su Ministarstvo zdravlja i Ministarstvo znanosti, obrazovanja i sporta (Marušić, 2014: 42). Na osnovi terenskih iskustava akteri su opetovano primijetili da se država nedovoljno koristi navedenim iskustvima OCD-a. Te su organizacije međusobno umrežene te opremljene kadrom, znanjima i vještinama u području neformalnog poučavanja hrvatskoga jezika, iako to nije primarni fokus njihova djelovanja. Takvo su iskustvo stekle kroz poučavanje fluktuirajuće i nestalno prisutne populacije stranih maloljetnika, premda je glavna karakteristika takva oblika pouke stalno počinjanje ispočetka s temeljnim jezičnim i sociokulturnim sadržajima (OCD, vjerske ustanove, HCK, UNHCR).

Ispitanici su naglasili i to da entuzijazam nevladina sektora kojim se pomaže učenicima u obrazovnom sustavu ne smije biti izlika za nesustavno

24 Igra, glazba, umjetnost, a posebno sport kod djece omogućuju integracijske procese kroz interakciju usprkos marginalizaciji zbog nepoznavanja jezika (Due i Riggs, 2009: 62; Marsh, 2012). 
uvođenje dodatnih oblika i sadržaja pomoći u učenju jezika i obrazovanju, nedovoljnu kapacitiranost kao ni za izostanak neovisnog nadzora i javnog predstavljanja rada Vladina sektora (CZSS, OCD, HCK, UNHCR, MSPM). $S$ druge strane, ispitanici iz obrazovnog sustava upozorili su na potrebu da država sama regulira način i učinkovitije obveže strane maloljetnike bez pratnje koji su jednom ušli u sustav da usvoje barem minimalno znanje hrvatskog jezika i pohađaju barem orijentacijsku godinu obrazovnog programa (DODM, OCD, SŠ). Time bi učenje jezika i obrazovanje stranih maloljetnika bez pratnje ubuduće eventualno mogli postati učinkovita polazna točka njihove primarne integracije u hrvatsko društvo.

\section{ZAKLJUČNA RAZMATRANJA}

Sukladno rezultatima našeg istraživanja, mjere učenja hrvatskog jezika (povijesti i kulture) i obrazovanja, iako propisane Protokolom i ostalim uredbama RH, spadaju u grupu manje prioritetnih aktivnosti unutar skrbi Vladinih i nevladinih, nacionalnih i međunarodnih tijela $\mathrm{u}$ vezi s pitanjem pomoći stranim maloljetnicima bez pratnje. One se pokreću tek po reguliranju statusno-egzistencijalnih pitanja, u koja ubrajamo imenovanje skrbnika i posebnu vrstu institucionalnoga smještaja, uz zadržavanje slobode kretanja. Ponavljamo kako upravo te odrednice status stranih maloljetnika bez pratnje čine povoljnijim u odnosu na odrasle neregularne migrante, koji kao, pretpostavljeno, mlađi punoljetnici nastoje zadobiti taj status vlastitom izjavom o maloljetnosti.

Hrvatska kao nova država Europske unije bilježi fenomen kratkoga i tek tranzitnog zadržavanja te pojave neregularnog napuštanja relevantnih institucija stranih maloljetnika bez pratnje. No jednak fenomen nakon pristupanja Europskoj uniji bilježila je i susjedna Slovenija (Gornik, 2009: 124). S jedne strane, njihov prosječno kratkotrajan boravak u Hrvatskoj i napuštanje sustava unutar nekoliko dana ili tjedana onemogućuju realizaciju državnog programa skrbi zajamčenog zakonskim okvirom, posebno u učinkovitom planiranju i realizaciji daljnjih aktivnosti u njihovu obrazovanju (DODM, UNHCR, MSPM). S druge pak strane, problem za govornike neslavenskoga govornog područja koji dolaze iz azijskih i afričkih zemalja predstavlja i hrvatski kao »težak jezik «, stoga što stranome maloljetniku bez pratnje izostaje podrška obitelji i šire zajednice u učenju i obrazovanju na hrvatskom jeziku (vjerske ustanove, OŠ, SŠ). Uočljivo je naime da su maloljetnici s pratnjom (članovima obitelji) u RH bili češće poticani na obrazovanje i učenje 
hrvatskog jezika. ${ }^{25}$ Vjerojatno je riječ i o percepciji hrvatskoga kao jezika države koja im nije primarna destinacija, već eventualno tranzitna zemlja, pa je zamjetna i veća motivacija za učenje njemačkoga ili engleskoga jezika (Anderson, 2001: 189-190; Maegusuku-Hewett i sur., 2007; OCD).

Skromno hrvatsko iskustvo s prisutnošću djece bez pratnje upozorilo je na manjkavosti i nepripremljenost sustava, primjerice za predškolsko uključivanje u sustavnu edukaciju, jer to ne spada u obavezno školovanje, kao ni ono nakon šesnaeste godine života. Osim normativne razine zajamčenosti zakonskih prava na obrazovanje razina implementacijskih praksi upućuje na nedovoljnu i bitno narušenu funkcionalnu integraciju stranih maloljetnika bez pratnje $\mathrm{u}$ obrazovne ustanove i u šire društvene tokove. Na terenu $\mathrm{u}$ Kutini pokazalo se kako je za sve vrijeme smještenosti Prihvatilišta za tražitelje azila ondje (dakle od lipnja 2006. do srpnja 2013., kada je Prihvatilište bilo privremeno zatvoreno radi preuređenja) od svih 606 slučajeva imenovanja posebnih skrbnika maloljetnim tražiteljima azila bila zabilježena tek nekolicina slučajeva pohađanja nastave $\mathrm{u}$ školama grada Kutine (desetak u osnovnoj i četvero u srednjoj školi) (prema CZSS-u). Naravno, i to valja zahvaliti njihovu brzom napuštanju sustava i teritorija.

Stoga, s obzirom na tranzitni karakter neregularnih kretanja većine stranih maloljetnika bez pratnje, njihovoj integraciji u hrvatsko društvo pridaje se tek sekundarna važnost. Jednako tako minorizira se i potreba učenja hrvatskog jezika i uključivanja maloljetnika u obrazovni sustav. Službeni je stav državnih tijela (MUP, CZSS) kako su strani maloljetnici bez pratnje uglavnom nevoljni pohađati školu ili se uključiti u druge oblike edukacijskih aktivnosti (MUP, HCK). Zamjetna je i strukturna, tj. pravna prepreka njihovu pohađanju škole: naime većina stranih maloljetnika bez pratnje koji su tražitelji azila u dobi je od šesnaest i sedamnaest godina (čak njih $86 \%$, prema podacima MUP-a), a sukladno Zakonu o odgoju i obrazovanju u osnovnoj i srednjoj školi, djeci iznad petnaest godina nije dostupno besplatno obrazovanje, što se svakako odražava na stupanj polaznosti škola stranih maloljetnika bez pratnje.

25 Istraživanje Smyth, Shannon i Dolan (2015: 12) upozorilo je da je zbog bitne suženosti i ograničenja ili potpunog izostanka društvene potpore (roditelja i šire obitelji) stranim maloljetnicima bez pratnje još važnije osigurati formalnu podršku koja uključuje pravno zastupništvo i skrbništvo, ali i kvalitetnu edukaciju i osmišljeno slobodno vrijeme putem poluformalnih ili neformalnih kanala. Slično tome, istraživanje Sigona i Hughes (2012: 31-33) u Velikoj Britaniji pokazalo je kako je populacija djece neregularnih migranata ondje većinom u pratnji roditelja te je stoga i roditeljima stalo do sustavne jezične integracije i dobre socijalizacije njihove djece. Tako ondje, u jednome mnogo značajnijemu multietničkom i multikulturnom okruženju, sama škola nastoji aktivno smanjiti diskriminaciju novopridošle djece, koja su u početku osjetljiva na novi obrazovni sustav i modele poučavanja. 
Također, često ostaje nejasnom podjela nadležnosti i odgovornosti u pogledu obrazovanja stranih maloljetnika između MUP-a, obrazovnog susta$v a, t j$. škola, te centara za socijalnu skrb. Međuresorna i unutarresorna nekoordiniranost i suviše fleksibilna, odnosno permisivna legislativa (DODM, CZSS, OCD) rezultiraju institucionalnim poteškoćama i nedosljednošću u implementaciji postojećih zakona i pravilnika te stavki iz aktualne »Migracijske politike Republike Hrvatske za razdoblje 2013. - 2015.« (Vlada RH, 2013b). Takvo stanje loše koordiniranosti rezultira i smanjenom funkcionalnošću sustava, a dijelom i zlouporabom prava koja strani maloljetnici imaju, no još više služi kao opravdanje samog sustava za svojevrsnu strukturnu institucionalnu blokadu u ostvarivanju njihovih prava (OCD). Osim učenja hrvatskog jezika hrvatske škole općenito pružaju slabu podršku migrantskim učenicima, a osim posebnih fondova za dodatno financiranje djece migrantskog porijekla izostaju i sredstva za obuku osoblja zaposlenog u školama, što dodatno potvrđuju i rezultati MIPEX-a (Vankova i sur., 2014).

Usto, ni sustavna edukacija stručnih službi koje se takvom djecom bave nije postala uobičajena praksa u nadležnim ustanovama (Kraljević, Marinović i Žigante Živković, 2011: 11, 63). Problem jezika tako je evidentan ne samo u nepokrivenosti cijelog spektra stranih jezika kojima se komunicira sa stranim maloljetnicima bez pratnje nego i u smislu nedovoljnih interkulturnih kompetencija za rad s osobama kulturnih, jezičnih, obrazovnih i ostalih društvenih različitosti. Za dijete u stresnim uvjetima nemogućnost komunikacije na poznatom jeziku može biti posebno frustrirajuća ako nije u stanju izraziti vlastite strahove, potrebe i teškoće, da bi na njih skrbnici i ostali akteri mogli odgovoriti (Babić, 2014: 149). Strani maloljetnici nisu homogena skupina s istim problemima, no s obzirom na najčešće prisutnu kratkoću boravka i izostanak motivacije i fokusiranog angažmana vezanog uz učenje jezika te ostanka u RH onemogućena im je ili barem otežana integracija u društvo, pogotovo na temelju jezične akulturacije (Phinney i sur., 2001).

Pitanje stranih maloljetnika bez pratnje još uvijek nije podignuto na razinu koju je u preporukama naznačila inicijativa UNHCR-a još 2011., odnosno nije imenovana središnja koordinacijska točka u RH koja bi se bavila nadzorom svih aktivnosti koje se provode s tom djecom, poslije definiranima Protokolom i drugom važećom pravnom regulativom (Vlada $\mathrm{RH}$, 2013a: 2-3). U zaštiti i procesu uključivanja stranih maloljetnika bez pratnje u društvo nismo zamijetili značajniji angažman UNICEF-ova ureda u Hrvatskoj, što nalazimo bitnim nedostatkom samog sustava u sustavnoj brizi za prava djece stranaca. 
U ovome smo se radu fokusirali na pravne i organizacijske aspekte uključivanja stranih maloljetnika bez pratnje $u$ formalni obrazovni proces i neformalne programe poučavanja jezika. Pristup "postmigracijske ekologije« omogućio je analizu strukturnih preduvjeta, tj. obrazovnih politika, te formalnih i neformalnih edukacijskih mjera za strane maloljetnike bez pratnje. Istraživanje je pokazalo kako u hrvatskom kontekstu postoji politika poučavanja jezika i obrazovanja kako djece stranaca i posebno djece koji su u nekom statusu zaštite, tako i odraslih. Dugo je izostajao formalni, od države organizirani tečaj učenja jezika za izbjeglice, a nedavni početak njegove provedbe kroz sustav organiziranoga institucionalnog učenja jezika nije praktično ni sustavno posve zaživio. Kompenzaciju su dijelom predstavljali suplementarni programi učenja jezika koje su provodili OCD, kulturne i vjerske ustanove, iako su oni istovremeno predstavljali i općenitije, neformalnije sadržaje socijalizacije i pomoći.

Nadalje, mnoga pravna jamstva obrazovnog sustava ne korespondiraju s organizacijskim odgovorima njegovih provedbenih jedinica (prije svega osnovnih i srednjih škola). Iako u organizacijskom aspektu u RH, zbog nevelikog broja stranih učenika, ne postoje tzv. »uvodni/tranzicijski razredi« kao u švedskome modelu, koji i fizički segregiraju novopridošle učenike stranog porijekla od domaćih (Nilsson i Bunar, 2015: 7), u hrvatskim osnovnim i srednjim školama pozitivnu praksu predstavlja provedba pripremne i dopunske nastave za strane učenike. Ostali organizacijski izazovi (komunikacija sa stručnim službama, dodatna mentorska nastava, stipendiranje i nastava za maloljetnike nezakonite migrante) ostaju dijelom neimplementirani zbog nepostojanja volje za provedbom u kontekstu koji karakterizira rano napuštanje sustava od za njega predviđenih korisnika.

Neadekvatna implementacija obrazovnih politika vodi isključivanju stranih maloljetnika bez pratnje iz obrazovnog procesa prije svega zato što je njihov boravak u RH transmigracijski (tranzitni) fenomen, a ne postmigracijski. Pritom je vrlo teško očekivati da pravna jamstva i obrazovni proces uistinu posluže kao preduvjet prvotne integracije stranih maloljetnika bez pratnje u šire društvene tokove. No kako je naša analiza pokazala, pravni i organizacijski aspekti učenja jezika i obrazovanja zahtijevaju osmišljavanje mjera za ostvarenje dugoročnog i održivog rješenja za strane maloljetnike bez pratnje koje bi podrazumijevalo njihov ostanak i lokalnu integraciju u hrvatsko društvo. 


\section{LITERATURA}

Ager, A. i Strang, A. (2008). Understanding Integration: A Conceptual Framework, Journal of Refugee Studies, 21 (2): 166-191, doi: 10.1093/jrs/fen016.

Anderson, A., Hamilton, R., Moore, D., Loewen, S. i Frater-Mathieson, K. (2004). Education of refugee children: theoretical perspectives and best practice, $\mathrm{u}$ : $\mathrm{R}$. Hamilton i D. Moore (ur.). Educational Interventions for Refugee Children: Theoretical Perspectives and Implementing Best Practice. London: Routledge - Falmer, 1-11.

Anderson, P. (2001). "You Don't Belong Here in Germany...": On the Social Situation of Refugee Children in Germany, Journal of Refugee Studies, 14 (2): 187-199, doi: 10.1093/ jrs/14.2.187.

Babić, G. (2014). Zaštita djece bez pratnje u sustavu socijalne skrbi, u: A. Korać Graovac (ur.). Pravna zaštita djece bez pratnje. Zagreb: Pravni fakultet Sveučilišta u Zagrebu, 145-153.

Bartholet, E. (2004). The challenge of children's rights advocacy: problems and progress in the area of child abuse and neglect, www.law.harvard.edu/faculty/bartholet/pdfs/ whittier.pdf (13. 03. 2015.).

Bhabha, J. (2004). Seeking Asylum Alone: Treatment of Separated and Trafficked Children in Need of Refugee Protection, International Migration, 42 (1): 141-148, doi: 10.1111/j.0020-7985.2004.00277.x.

Bryman, A. (2008). Social Research Methods. Oxford: Oxford University Press.

Bužinkić, E. i Kranjec, J. (2012). Integracijske politike i prakse u sustavu azila u Republici Hrvatskoj. Zagreb: Centar za mirovne studije.

Castro Feinberg, R. (2000). Newcomer School: Salvation or Segregated Oblivion for Immigrant Students?, Theory into Practice, 39 (4): 220-227, doi: 10.1207/ s15430421tip3904_5.

Češi, M., Cvikić, L. i Milović, S. (2012). Inojezični učenik u okruženju hrvatskoga jezika: Okviri za uključivanje inojezičnih učenika u odgoj i obrazovanje na hrvatskome jeziku. Zagreb: Agencija za odgoj i obrazovanje, www.azoo.hr/images/izdanja/Inojezicni_ucenik _web.pdf (07. 03. 2015.).

Derluyn, I. i Broekaert, E. (2008). Unaccompanied refugee children and adolescents: the glaring contrast between a legal and a psychological perspective, International Journal of Law and Psychiatry, 31 (4): 319-330, doi: 10.1016/j.ijlp.2008.06.006.

Due, C. i Riggs, D. (2009). Moving Beyond English as a Requirement to "Fit In": Considering Refugee and Migrant Education in South Australia, Refuge: Canada's Journal on Refugees, 26 (2), 55-64.

Ensor, M. O. (2010). Understanding Migrant Children: Conceptualizations, Approaches, and Issues, u: M. O. Ensor i E. M. Gozdziak (ur.). Children and Migration: At the Crossroads of Resiliency and Vulnerability. New York: Palgrave Macmillan, 15-35.

Flick, U. (1998). An Introduction to Qualitative Research. London: Sage.

Gornik, B. (2009). Mladoletni migranti brez spremstva in njihove pravice v slovenskem azilnem in migracijskem sistemu, Razprave in gradivo, (60): 118-141.

Hrvatski pravni centar - HPC (2012). National Report on the Asylum System from 2010 to 2012, www.hpc.hr/download.aspx?f=dokumenti/Razno/Nationalreport onasylumsystem.pdf (08. 03. 2015.). 
Institut za migracije i narodnosti (2015). Tokovi prisilnih migracija i humanitarna kriza u Europi: strateška polazišta Instituta za migracije i narodnosti. Zagreb: Institut za migracije i narodnosti, http://imin.hr/strateska-polazista (25. 11. 2015.).

International Committee of the Red Cross - ICRC (2014). Children and Detention. Geneva.

Jelavić, M. (ur.) (2008). Djeca bez pratnje: djeca stranci odvojeni od roditelja. Zagreb: Pravobranitelj za djecu, http://www.dijete.hr/hr/publikacijepravobranitelja/doc_ details/17-djeca-bez-pratnje.html (11. 10. 2014.).

Korać Graovac, A. (ur.). (2014). Pravna zaštita djece bez pratnje: zbornik radova sa znanstvenostručnog skupa. Zagreb: Pravni fakultet Sveučilišta u Zagrebu.

Kraljević, R., Marinović, L. i Žigante Živković, B. (2011). Djeca bez pratnje strani državljani u Republici Hrvatskoj. Zagreb: UNHCR.

Kuti, S. (2014). Integration Policies: Country Report for Croatia. Migration Policy Centre (EUI, Florence, Italy), INTERACT Research Report, Country Report; 2014/13.

Maegusuku-Hewett, T., Dunkerley, D., Scourfield, J. i Smaley, N. (2007). Refugee Children in Wales: Coping and Adaptation in the Face of Adversity, Children and Society, 21 (4): 309-321, doi: 10.1111/j.1099-0860.2007.00102.x.

Marsh, K.(2012). “Thebeat will makeyou be courage": The role of a secondary school music program in supporting young refugees and newly arrived immigrants in Australia, Research Studies in Music Educations, 34 (2): 93-111, doi: 10.1177/1321103×12466138.

Marušić, D. (2014). Zaštita djece bez pratnje u sustavu socijalne skrbi, u: A. Korać Graovac (ur.). Pravna zaštita djece bez pratnje: zbornik radova sa znanstveno-stručnog skupa. Zagreb: Pravni fakultet Sveučilišta u Zagrebu, 39-48.

Ministarstvo unutrašnjih poslova - MUP (2014). Statistika o maloljetnicima bez pratnje u RH, na dan 31.7.2014., privatna korespondencija (13. 08. 2014.).

Ministarstvo unutarnjih poslova - MUP (2015). Statistički pokazatelji maloljetnika bez pratnje prema dobi i spolu koji su zatražili međunarodnu zaštitu u Republici Hrvatskoj, http://www.mup.hr/UserDocsImages/Dokumenti/stranci/2015/trazitelji_ medunarodne_zastite_12_10_15.pdf (02.11. 2015.).

Ministarstvo znanosti, obrazovanja i sporta - MZOS (2011). Program hrvatskoga jezika za pripremnu nastavu za učenike osnovne i srednje škole koji ne znaju ili nedovoljno poznaju hrvatski jezik, Narodne novine, 151/2011.

Ministarstvo znanosti, obrazovanja i sporta - MZOS (2012). Odluka o elementima i kriterijima za izbor kandidata za upis u srednje škole u školskoj godini 2012/2013, http://www.azoo.hr/images/razno/Odluka_o_upis_u_srednje_skole.pdf (05. 03. 2015.).

Ministarstvo znanosti, obrazovanja i sporta - MZOS (2013). Pravilnik o provođenju pripremne i dopunske nastave za učenike koji ne znaju ili nedostatno znaju hrvatski jezik i nastave materinskoga jezika i kulture države podrijetla učenika, Narodne novine, 15/2013, http://www.propisi.hr/print.php?id=12132, (05. 03. 2015.).

Nilsson, J.iBunar, N. (2015). Educational Responses to Newly Arrived Students in Sweden: Understanding the Structure and Influence of Post-Migration Ecology, Scandinavian Journal of Educational Research, (online), doi: 10.1080/00313831.2015.1024160.

Nonchev, A. i Tagarov, N. (ur.) (2012). Integrating Refugee and Asylum-Seeking Children in the Educational Systems of EU Member States. Sofia: Center for the Study of Democracy - CSD, www.csd.bg/fileadmin/user_upload/INTEGRACE_handbook.pdf (17. 11. 2014.). 
Phinney, J., Horenczyk, G., Liebkind, K. i Vedder, P. (2001). Ethnic identity, immigration and well-being: an interactional perspective, Journal of Social Issues, 57 (3): 493-510, doi: 10.1111/0022-4537.00225.

Pinson, H., Arnot, M. i Candappa, M. (2010). Education, Asylum and the 'Non-Citizen' Child: The Politics of Compassion and Belonging. New York: Palgrave Macmillan, doi: 10.1057/9780230276505.

Sigona, N. i Hughes, V. (2012). No Way Out, No Way In: Irregular Migrant Children and Families in the UK, Research report. Oxford: Centre of Migration, Policy and society, University of Oxford.

SIRIUS (2013). European Policy Network on the education of children and young people with a migrant background: Position paper. http://www.sirius-migrationeducation. org/wp-content/uploads/2013/06/Position-paper_EN.pdf (27. 11. 2014.).

Smyth, B., Shannon, M. i Dolan, P. (2015). Transcending borders: Social support and resilience, the case of separated children, Transnational Social Review, (online), doi: 10.1080/21931674.2015.1074430.

Thatun, S. i Heissler, K. (2013). Children's migration: Towards a multidimensional child protection perspective, $\mathrm{u}$ : Children on the Move. Geneva: IOM, 95-108, doi: $10.18356 / 3 f 6158 b c-e n$.

Ting, T. (2014). Unaccompanied Minors in Croatia - A Comparative Perspective: Analysing the Polices vs. Practices. Final Report, European Master in Migration and Intercultural Relations, University of Stavanger - Institute for Migration and Ethnic Studies, Zagreb.

UNHCR (2008). UNHCR Guidelines on Determining the Best Interests of the Child. Geneva, www.unhcr.org/4566b16b2.pdf (07. 11. 2014.).

UNHCR (2015). Europe Refugee Emergency - Briefing Note: Unaccompanied and separated children, http://data.unhcr.org /mediterranean/download.php?id=85 (23. 11. 2015.).

UNICEF (2015). Regional Humanitarian Situation Report \#3: Refugee and Migrant Crisis in Europe, 9 November 2015, www.unicef.org/appeals/files/UNICEF_Regional_ SitRep_9_Nov_2015.pdf (17. 11. 2015.).

United Nations General Assembly -UN (1989). Convention on the Rights of the Child, UNTS, 1577, 20. 11. 1989, www.refworld.org/docid/3ae6b38f0.html (09. 01. 2015.).

Valenta, M., Zuparic-Iljic, D. i Vidovic, T. (2015). The Reluctant Asylum-Seekers: Migrants at the Southeastern Frontiers of the European Migration System, Refugee Survey Quarterly, 34 (3): 95-113, doi: 10.1093/rsq/hdv009.

Vankova, Z., Gregurović, S., Župarić-Iljić, D., Kranjec, J., Lalić Novak, G., Špadina, H., i Zlatković Winter, J. (2014). Hrvatska - Indeks razvijenosti politika integracije migranata (MIPEX), http://www.imin.hr/c/document_library/get_file?uuid=59d7e46c-51524a8d-ad14-a296e468d6ca\&groupId=10156 (14. 02. 2015.).

Vlada RH (2013a). Protokol o postupanju prema djeci odvojenoj od roditelja stranim državljanima, 18. 07. 2013. http://www.mspm.hr/content/download/ 11886/92190/version/1/file/Protokol+prema+djeci+odvojenoj+od+roditelja++stranim+dr\%C5\%Beavljani ma.pdf (11. 11. 2014.)

Vlada RH (2013b). Migracijska politika Republike Hrvatske za razdoblje 2013. - 2015., Narodne novine, 27/2013.

Watters, C. (2008) Refugee Children: Towards the Next Horizon. Oxon: Routledge. 
Wernesjö, U. (2012). Unaccompanied asylum-seeking children: Whose perspective? Childhood, 19 (4): 495-507, doi: 10.1177/0907568211429625.

Zakon o međunarodnoj i privremenoj zaštiti, Narodne novine, 70/2015.

Zakon o odgoju i obrazovanju u osnovnoj i srednjoj školi, Narodne novine, 87/2008, 86/2009, 92/2010, 105/2010, 90/2011, 5/2012, 16/2012, 86/2012, 94/2013, 136/2014 RUSRH, 152/2014.

Zdravković, L. (2011). Integrating Refugee and Asylum-Seeking Children in the Educational Systems, Country Report: Croatia, http://www.csd.bg/fileSrc.php?id=20752, (05. 03. 2015.). 


\title{
Foreign Unaccompanied Minors in the Republic of Croatia: the Issue of Language Learning and Education
}

\author{
Drago Župarić-lljić, Dubravka Mlinarić
}

\begin{abstract}
SUMMARY
Modern mixed migration flows include children separated from their parents and unaccompanied minors, who are among the most vulnerable groups of migrants. From 2006 to July 2014, a total of 3255 foreign unaccompanied minors were registered in Croatia, of whom about 400 were asylum seekers, mainly citizens of Afghanistan, Pakistan and Somalia. It is obvious that they stay shortly in the institutions entitled for their care and arbitrarily leave them within just a few weeks from the day of arrival. Policies and measures aimed at the welfare and protection of foreign unaccompanied minors include state mechanisms in the domains of establishing the identity and age of a minor, appointment of a guardian, ensuring accommodation and freedom of movement, legal and financial support, health and social care, language learning, education and ensuring their reunification with family. The focus of this paper is on the analysis of policies and measures related to language learning and the education of foreign unaccompanied minors, which is one of the basic prerequisites of their inclusion in society. Based on research conducted by the interview method among the relevant actors involved in the system of their protection and care, some of the most important challenges, primarily in the field of educational, but also of the broader integration of foreign unaccompanied minors have been analysed. Preliminary results suggest that their brief stay in Croatia and early drop-out of the system prevents the implementation of the national care program guaranteed by the legal framework, which partly makes it impossible for the state to systematically and effectively plan and implement further activities in the education of children of foreigners. Lack of inter-agency and intra-agency coordination within the government sector leads in this area to institutional problems and inconsistency in the implementation of the existing national regulations and European standards.
\end{abstract}

KEY WORDS: unaccompanied minors, language learning, education, integration policies, Croatia 